\title{
Pengaruh Penyungkupan Terhadap Pertumbuhan Bibit Kakao (Theobroma cocoa L.) Perbanyakan Generatif
}

\author{
I Ketut Suwitra, Muhammad Afif Juradi, Irwan Suluk Padang, Saidah, dan Hamka Biolan \\ Balai Pengkajian Teknologi Pertanian Sulawesi Tengah \\ Email: iketutsuwitra@ymail.com
}

\begin{abstract}
ABSTRAK
Kakao merupakan komoditas perkebunan yang memegang peranan penting dalam perekonomian Indonesia namun produktivitasnya akhir-akhir ini mengalami penurunan akibat tanaman kakao yang diusahakan umurnya rata-rata lebih dari 30 tahun. Oleh sebab itu perlu dilakukan inovasi teknologi terkait rehabilitasi tanaman melalui perbanyakan generatif bibit kakao. Penelitian ini bertujuan untuk menghasilkan daya tumbuh dan pertumbuhan bibit kakao yang optimal. Perlakuan yang diujikan adalah penggunaan sungkup plastik setelah tanam benih selama 1 bulan dibandingkan dengan tanpa penggunaan sungkup yang di laksanakan di rumah bibit Kebun Percobaan Sidondo BPTP Sulawesi Tengah. Hasil penelitian menunjukkan bahwa penggunaan sungkup setelah tanam benih selama satu bulan memberikan hasil terbaik terhadap daya tumbuh, tinggi tanaman, diameter batang dan jumlah daun yang terbentuk pada bibit kakao. Penggunaan sungkup dapat mempertahankan tingkat kelembaban udara yang tinggi sehingga dapat menghemat penggunaan air untuk penyiraman dibandingkan tanpa menggunakan sungkup.
\end{abstract}

Kata Kunci : sungkup, bibit kakao, pertumbuhan

\section{PENDAHULUAN}

Tanaman kakao (Theobroma cocoa L) merupakan komoditas perkebunan yang memegang peranan penting dalam perekonomian Indonesia. Sulawesi Tengah merupakan pemasok/produsen kakao kedua terbesar setelah Sulawesi Selatan kemudian diikuti oleh Sulawesi Barat. Produksi Kakao Sulawesi Tengah sebesar 158.278 ton/thn dengan luas areal penguasaan 289.274 ha, merupakan sumber penghasilan terbesar para petani (Dinas Perkebunan, 2016). Hal ini menunjukkan bahwa produktivitas tanaman kakao hanya mencapai $547,2 \mathrm{~kg} / \mathrm{ha} /$ tahun, jauh lebih rendah dari rata-rata potensi hasil tanaman kakao sebesar 1,5 ton/ha/tahun. Masih terdapatnya kesenjangan hasil (yield gap) antara potensi hasil tanaman kakao dengan realita hasil di lapangan merupakan peluang yang harus dimanfaatkan.

Salah satu pemicu rendahya produktivitas tanaman kakao di Sulawesi Tengah adalah umur tanaman kakao yang diusahakan oleh para petani telah tidak produktif lagi. Rata-rata umur tanaman kakao lebih dari 15 tahun. Salah satu upaya yang dilakukan untuk mengatasi hal tersebut adalah melalui rehabilitasi tanaman kakao dengan melakukan penanaman kembali dengan mengintroduksikan klon-klon kakao unggul nasional yang memiliki produktivitas dan kualitas biji yang tinggi (Sahardi dan Fadjry, 2015). Klon-klon kakao unggul nasional yang telah beradaptasi dengan baik di Sulawesi Tengah diantaranya TSH 858, UIT 1, GC 7, ICS 13, ICS 60, RCC 71, RCC 72 dan Pa 300 (Suwitra, 2006). Introduksi klon-klon tersebut dapat dilakukan melalui perbanyakan generatif dan vegetatif. Perbanyakan vegetatif misalnya sambung samping, okulasi dan sambung pucuk. Keuntungan dari metode ini adalah tanaman kakao lebih cepat berproduksi. Pada umur tanaman 18 bulan telah berbuah dan pada umur 3 tahun telah mampu menghasilkan 15-22 buah/pohon (Suhendi, 2008). Perbanyakan melalui sambung pucuk memiliki keunggulan dibandingkan okulasi, yakni pertumbuhan tanaman lebih cepat dan mudah untuk dilakukan (Nappu et al. 2015). Sambung pucuk 
merupakan salah satu metode perbanyakan bibit kakao yang dapat dilakukan secara massal dalam waktu yang relatif cepat. Keberhasilan hasil sambungan lebih dari 90\% (Winarsih, 1999, Basri, 2009).

Untuk mendapatkan hasil perbanyakan vegetatif yang baik dibutuhkan dukungan kualitas batang bawah yang baik pula. Pengembangan perbanyakan tanaman kakao secara generatif sebagian besar menggunakan benih hibrida (F1) yang lebih murah dan mudah untuk dilakukan. Keunggulan dari perbanyakan ini adalah menghasilkan perakaran tanaman yang lebih kuat, memiliki umur produktif yang sama dan memiliki keragaan genetik yang lebih banyak. Permasalahan yang dihadapi pada perbanyakan generatif adalah rendahnya daya tumbuh benih serta belum optimalnya pertumbuhan bibit kakao untuk memdukung perbanyakan vegetatif atau di tanam secara langsung di lahan pertanian. Oleh sebab itu tujuan dari penelitian ini adalah untuk mengetahui pengaruh penyungkupan terhadap daya tumbuh dan pertumbuhan bibit kakao yang diperbanyak secara generatif.

\section{METODOLOGI}

Penelitian ini dilakukan di rumah bibit Kebun Percobaan Sidondo BPTP Sulawesi Tengah bulan Juli hingga September 2017 untuk mengetahui pengaruh penggunaan sungkup terhadap daya tumbuh dan pertumbuhan bibit kakao hibrida (F1). Menggunakan uji T untuk membandingkan dua perlakuan yakni bibit kakao yang disungkup dan tanpa disungkup. Penyungkupan ini dilakukan selama satu bulan terhitung mulai benih ditanam. Jumlah tanaman yang digunakan masing-masing 1000 bibit. Peubah yang diamati adalah Jumlah benih yang tumbuh, tinggi tanaman, diameter batang, jumlah daun, suhu dan kelembaban udara. Pengamatan dilakukan dua kali yakni pada umur 30 dan 60 hari setelah tanam.

Pelaksanaan penelitian dilakukan dengan tahapan sebagai beikut : pengisian polibag dengan media tanam, penataan polibag, perlakuan benih, penanaman benih dan penyungkupan. Pengisian polibag. Polibag yang digunakan berukuran $17 \mathrm{~cm} \times 25 \mathrm{~cm}$ diisi media tanam berupa tanah, pupuk kandang dan pasir dengan perbandingan 2 : 1 : 1 . Penataan Polibag. Polibag diatur dan ditata 10 baris sepanjang 12 meter sehingga terdapat 1000 polibag dalam setiap barisnya. Perlakuan benih. Benih yang digunakan merupakan benih hibrida (F1) yang bersumber dari Puslitkoka Jember. Benih terlebih dahulu direndam menggunakan fungisida selanjutnya dibilas dengan air bersih. Penanaman benih. Benih ditanam dengan cara memasukkan benih ke lubang tanam yang telah dibuat ditengah-tengah media tanam pada polibag dengan memasukkan benih sedalam $\pm 1 / 4$ dari pajang benih dengan titik tumbuh menghadap ke bawah. Penyungkupan. Sebelum pemasangan sungkup terlebih dahulu dipasang rangka sungkup yang terbuat dari bambu berjarak $1.5 \mathrm{~m}$. Sungkup terbuat dari plastik dengan ketebalan $0.2 \mathrm{~mm}$, berwarna putih transparan dipasang setelah dilakukan penanaman benih. Selanjutnya dilakukan pemeliharaan bibit seperti penyiraman dan pengendalian hama dan penyakit.

\section{Daya Tumbuh}

\section{HASIL DAN PEMBAHASAN}

Pengertian dari daya tumbuh adalah munculnya unsur-unsur utama dari lembaga benih dan menunjukkan kemampuan untuk menjadi tanaman normal bila ditanam pada lingkungan yang sesuai bagi tanaman tersebut. Setelah umur 30 hari terlihat dengan perlakuan disungkup memberikan daya tumbuh yang sangat tinggi sebesar $95.5 \%$ dibandingkan tanpa di sungkup sebesar $76.1 \%$. Kematian bibit tanpa perlakuan penyungkupan disebabkan karena flush dan batang kakao tertempel oleh percikan tanah akibat air hujan sehingga tanaman tidak tumbuh optimal bahkan mengalami kematian hingga daun dan batang terlihat busuk dan kering. Sedangkan tingginya daya tumbuh bibit kakao pada perlakuan penyungkupan diakibatkan tidak terkontaminasinya bibit kakao dari air hujan dan kelembabannya cenderung lebih stabil dibandingkan tanpa penyungkupan. 


\section{Komponen Pertumbuhan}

Lingkungan khususnya iklim mikro dapat mempengaruhi komponen pertumbuhan tanaman. Bibit kakao tergolong sangat peka terhadap perubahan iklim, oleh sebab itu dibutuhkan kecermatan dalam proses budidaya pembibitan yang dilakukan secara massal. Komponen pertumbuhan bibit kakao yang diamati adalah tinggi tanaman, diameter batang dan jumlah daun. Rata-rata tinggi tanaman, diameter batang dan jumlah daun yang terbentuk dapat dilihat pada tabel 1 berikut ini.

Tabel 1. Rerata Tinggi tanaman, Diamter batang dan Jumlah daun yang terbentuk pada umur 30 dan 60 hari setelah tanam bibit kakao

\begin{tabular}{ccccccc}
\hline \multirow{2}{*}{ Perlakuan } & \multicolumn{2}{c}{ Umur 30 hari setelah tanam } & \multicolumn{3}{c}{ Umur 60 hari setelah tanam } \\
\cline { 2 - 7 } & $\begin{array}{c}\text { Tinggi } \\
\text { tanaman } \\
(\mathrm{cm})\end{array}$ & $\begin{array}{c}\text { Diameter } \\
\text { batang }(\mathrm{cm})\end{array}$ & $\begin{array}{c}\text { Jumlah } \\
\text { daun }\end{array}$ & $\begin{array}{c}\text { Tinggi } \\
\text { tanaman } \\
(\mathrm{cm})\end{array}$ & $\begin{array}{c}\text { Diameter } \\
\text { batang } \\
(\mathrm{cm})\end{array}$ & Jumlah daun \\
\hline Sungkup & $18.4 \mathrm{a}$ & $0.23 \mathrm{a}$ & $4.5 \mathrm{a}$ & $43.3 \mathrm{a}$ & $0.40 \mathrm{a}$ & $9.2 \mathrm{a}$ \\
\hline Tanpa Sungkup & $15.5 \mathrm{~b}$ & $0.26 \mathrm{a}$ & $4.6 \mathrm{a}$ & $28.9 \mathrm{~b}$ & $0.39 \mathrm{a}$ & $4.6 \mathrm{~b}$ \\
\hline
\end{tabular}

Keterangan : angka yang diikuti oleh huruf yang sama pada kolom yang sama tidak berbeda nyata pada uji lanjut BNT 5\%

Hasil pengamatan menunjukkan bahwa tinggi tanaman, diameter batang dan jumlah daun yang terbentuk dengan perlakuan penggunaan sungkup lebih baik dibandingkan tanpa menggunakan sungkup. Tinggi tanaman dipengaruhi oleh intensitas cahaya. Intensitas cahaya yang tinggi mengkibatkan tanaman menjadi lebih pendek (Sulistyaningsih et al. 2005). Lebih tingginya tanaman yang disungkup diduga karena auksin yang mempengaruhi pemanjangan sel bekerja lebih aktif dalam kondisi lebih gelap. Terpacunya pertumbuhan tinggi tanaman dalam kondisi gelap merupakan usaha tanaman untuk mendapatkan cahaya matahari. Muamar dan Maiyana (2014) melaporkan bahwa tanaman yang diberi sungkup lebih tinggi dibandingkan tanpa sungkup. Demikian pula terhadap komponen pertumbuhan dan daya tumbuh terlihat lebih optimal pada bibit kakao yang menggunakan sungkup. Hal ini diduga karena faktor iklim mikro yang terbentuk dapat mendukung pertumbuhan bibit kakao tersebut. Berikut ini disajikan gambaran suhu dan kelembaban yang terbentuk yang diamati selama tiga hari dengan durasi waktu 1 jam.

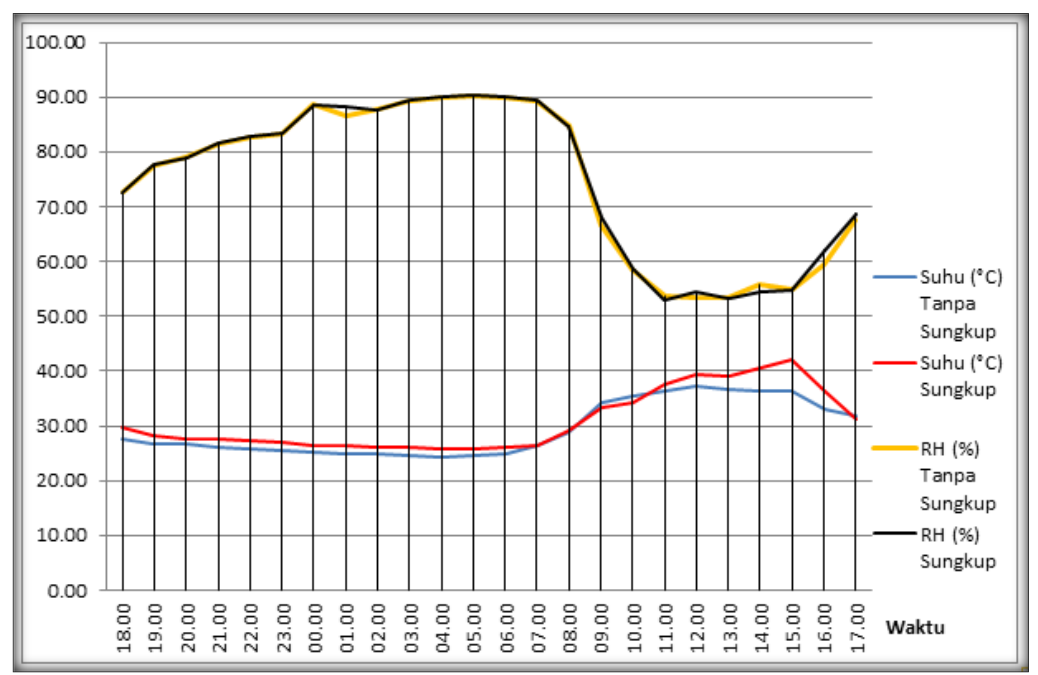

Gambar 1. Fluktuasi suhu dan kelembaban bibit kakao yang disungkup dan tanpa sungkup 
Hasil pengamatan menunjukkan bahwa semakin tingginya suhu dalam sungkup pada siang hari mengakibatkan semakin menurunnya kelembaban dalam sungkup. Suhu dalam sungkup terlihat lebih tinggi di malam hari hingga pagi hari (pukul $18.00-07.00$ ) namun lebih rendah hingga durasinya 3 jam pada pukul 08.00 - 10.00, selanjutnya puncak suhu tertinggi terjadi pada pukul 15.00. Kelembaban yang terbentuk dengan penggunaan sungkup relatif lebih rendah dan cenderung stabil dibandingkan tanpa menggunakan sungkup. Hal ini pula dilihat dari lengas tanah media tanam, dengan penyungkupan dapat menghemat pengunaan air (disiram hanya empat kali dalam satu bulan) sedangkan tanpa sungkup penyiraman dilakukan dua kali dalam satu hari. Penggunaan sungkup plastik dimaksudkan terutama untuk mempertahankan tingkat kelembaban udara yang tinggi (RH 70\%). Persemaian tanpa sungkup mengkibatkan laju transprirasi sering melampaui jumlah air yang tersedia untuk diabsorpsi oleh bibit tanaman (Zaubia et al., 1994). Tampilan bibit kakao yang disungkup dan tanpa sungkup dapat di lihat pada Gambar 2 berikut ini.

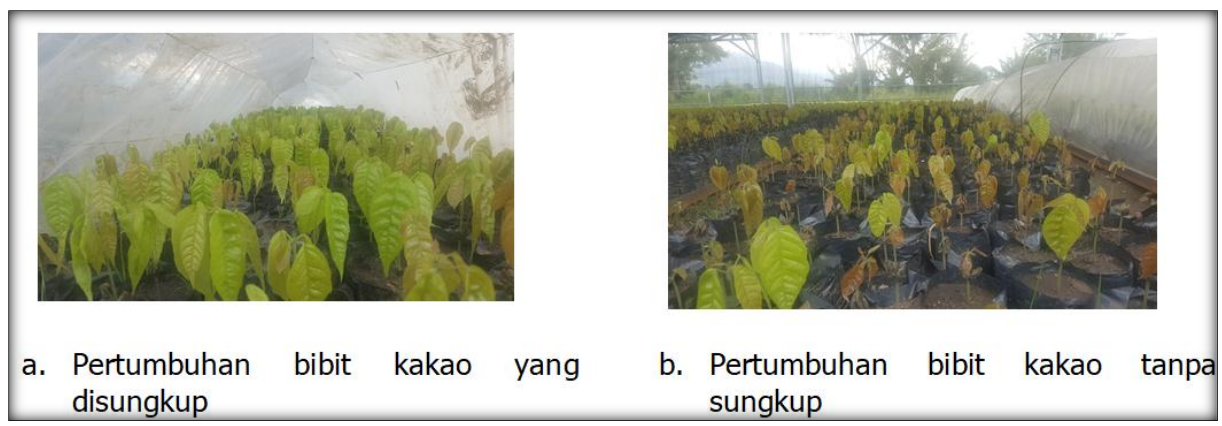

Gambar 2. Pertumbuhan bibit kakao yang disungkup dan tanpa sungkup

Terlihat bahwa pertumbuhan bibit yang disungkup memiliki tingkat keseragaman dan daya tumbuh yang lebih baik dibandingkan tanpa sungkup. Ini menunjukkan bahwa bibit tersebut telah dapat beradaptasi dengan baik terhadap lingkungan dan iklim setempat. Sehingga menunjukkan perkembangan tanaman yang normal dikarenakan ditanam pada kondisi lingkungan dan iklim yang sesuai (Suwitra dan Saidah, 2018). Untuk merawat bibit kakao di masa kritis (umur 1 bulan sejak tanam) maka penggunaan sungkup mutlak dilakukan untuk menghindari serangan jamur pada bibit kakao. Penyungkupan dengan plastik dapat menciptakan lingkungan tumbuh yang ideal bagi benih kakao, hal ini dikarenakan terkontrolnya pencahayaan, suhu dan kelembaban udara menjadi lebih seimbang sehingga proses metabolisme bibit kakao menjadi lebih baik.

\section{KESIMPULAN}

Penampilan pertumbuhan tanaman bibit kakao yang disungkup lebih baik dibandingkan dengan tanaman tanpa sungkup. Daya tumbuh bibit umur 1 bulan sebesar $95.5 \%$ jauh lebih tinggi dibandingkan tanpa sungkup sebesar $76.1 \%$.

\section{DAFTAR PUSTAKA}

Basri Z., 2009. Kajian Metode Perbanyakan Klonal pada Tanaman Kakao. Media Litbang Sulteng. 2 (1) : 07-14, Oktober 2009.

Larekeng Y. Sakka Samuddin dan Hendry Barus. 2017. Kajian Berbagai Lama Penyimpanan Entres Terhadap Hasil Sambung Samping Kakao (Theobroma cacao L) Klon Sulawesi. Jurnal Mitra Sains. Vo.5 No.1. 
Limbongan, J., 2011. Kesiapan Penerapan Teknologi Sambung Samping untuk Mendukung Program Rehabilitasi Tanaman Kakao. Jurnal Litbang Pertanian. 30 (4), 2011.

Limbongan J. Dan Langsa Y., 2006. Peremajaan Kakao dengan Klon Unggul melalui Teknik Sambung Samping (slide - cleft grafting) di Sulawesi Tengah. Prosiding Seminar Nasional. Pengembangan Usaha Agribisnis Industri Pedesaan. Palu.

Muamar R.M dan Maiyana. 2014. Pengaruh Penggunaan Sungkup Palstik Berwarna Terhadap Pertumbuhan Tanaman Sawi. JESBIO Vol.III No.5 November 2014.

Nappu, M. Basir, Jermia Limbongan, and Baso A. Lologau. "Perbanyakan Bibit Kakao Melalui Teknik Grafting, Okulasi, Dan Somatik Embriogenesis Di Provinsi Sulawesi Selatan." Jurnal Pengkajian dan Pengembangan Teknologi Pertanian 17.3 (2015).

Sahardi dan Fadjry Djufry, 2015. Keragaman Karakteristik Morfologis Plasma Nutfah Klon Harapan Kakao Lokal Sulawesi Selatan. Jurnal LITRI kakao, 05-10-2015.

Suhendi, D., 2008. Rehabilitasi Tanaman Kakao. Tinjauan Potensi Permasalahan dan Rehabilitasi tanaman kakao di Desa Primatani Tonggolobibi. Hal 335-346. Prosiding Seminar Nasional Pengembangan Inovasi Lahan Marginal. Pusat Peneltitan Kopi dan Kakao. Jember.

Sulistyaningsih E. Budiastuti Kurniasih dan Endah Kurniasih. 2005. Pertumbuhan dan Hasil Caisin pada Berbagai Warna Sungkup Plastik. Jurnal IImu Pertanian. Vol.12 No.1, 2005 ; 65-76.

Suwitra, IK., 2006. Visitor Plot dan Unit Komersilaisasi Teknologi di Kebun Percobaan Sidondo BPTP Sulawesi
Tengah. Laporan Hasil Tahunan BPTP Sulteng. 2006.

Suwitra dan Saidah. 2018. Pertumbuhan Vegetatif Tanaman Kakao (Theobroma coacoa L) Sambung Pucuk dengan Zat Pengatur Tumbuh (ZPT) dan Klon yang Berbeda di Sulawesi Tengah. Seminar Nasional. Perhinpunan Agronomi Indonesia. Bogor. P561-566.

Tirtawinata, M.R.,2003. Kajian Anatomi dan Fisiologi sambungan bibit Manggis dengan beberapa kerabat Cluciaceae. Program Pascasarjana IPB. Bogor.

Winarsih, S. 1999. Pedoman Teknis Sambung Pucuk Kakao. Warta Pusat Penelitian Kopi dan Kakao. 15(2):230-234.

Zaubia R. Supardiono dan Dani Purwadi. 1994. Pengaruh Warna Sungkup Plastik dan Konsentrasi Perangsang Tumbuh Atonik Terhadap Pertumbuhan Tanaman Lada di Persemaian. Buletin Litro. Vol.02 No.2 1994. 